\title{
PELAKSANAAN KREDIT PADA BANK PERKREDITAN RAKYAT LPN PASAR BARU DURIAN SAWAHLUNTO
}

\author{
Donna Eka Putri, Ratna Widayati \\ Akademi Keuangan dan Perbankan Padang \\ ratnawidayati@akbpstie.ac.id
}

\begin{abstract}
ABSTRAK
Kredit adalah kepercayaan dari kreditur (pemberian pinjaman) bahwa debiturnya (penerima pinjaman) akan mengembalikan pinjaman beserta bunganya sesuai dari perjanjian kedua belah pihak. Pelaksanaan kredit yang dilakukan oleh Bank Perkreditan Rakyat LPN Pasar Baru Durian Sawahlunto dimulai dari proses pemberian kredit hingga pengembalian kredit. Tujuan dari penelitian ini adalah untuk mengetahui proses pelaksanaan kredit, perkembangan kredit dan pengembalian kredit, masalah-masalah apa saja yang dihadapi oleh Bank Perkreditan Rakyat LPN Pasar Baru Durian Sawahlunto. Guna mendukung penelitian tugas akhir ini lebih sempurna diperlukan data akurat. Untuk itu data yang dikumpulkan peneliti adalah data sekunder dan data primer. Untuk pembahasan menggunakan metode penelitian yang berupa jenis data dan sumber data berupa data primer dan sekunder, sedangkan teknik pengumpulan data dengan metode observasi, metode wawancara, metode keperpustakaan. Metode yang digunakan adalah metode Deskriptif. Lokasi penelitian di Bank Perkreditan Rakyat LPN Pasar Baru Durian Sawahlunto. Obyek kajian dalam penelitian ini adalah pelaksanaan kredit pada Bank Perkreditan Rakyat LPN Pasar Baru Durian Sawahlunto. Dari hasil penelitian maka bisa disimpulkan bahwa pelaksanaan proses pemberian kredit yang dilakukan oleh Bank Perkreditan Rakyat LPN Pasar Baru Durian Sawahlunto dimulai dari pengajuan berkas, penyelidikan berkas pinjaman, keputusan kredit, dan diakhiri dengan realisasi kredit. Setelah itu barulah dilakukan pengawasan kredit. Permasalahan yang dihadapi oleh Bank Perkreditan Rakyat LPN Pasar Baru Durian masih adanya nasabah yang membayar tidak pada waktunya.
\end{abstract}

Kata Kunci : Proses pemberian kredit, masalah kredit

\section{PENDAHULUAN}

Dunia perbankan sebagai pelaku ekonomi merupakan salah satu lembaga keuangan yang turut serta dan ikut berpartisipasi dalam pemerataan pembangunan. Oleh karena itu, bank harus bertindak efektif dan efisien. Efektif 
berarti bahwa bank harus menyimpan dana, mampu memberi kredit dan memberikan jasa pelayanan lainnya, sedangkan arti efisien adalah bagaimana kerja bank tersebut bagus dalam kegiatan operasionalnya untuk mencapai tujuan di dalam perbankan.

Pasal 3 dan 4 Undang-undang Nomor 7 Tahun 1992 juncto Undang-undang Nomor 10 Tahun 1998 tentang Perbankan menyebutkan bahwa fungsi utama Perbankan Indonesia adalah sebagai penghimpun dan penyalur dana masyarakat yang bertujuan menunjang pelaksanaan pembangunan nasional ke arah peningkatan kesejahteraan rakyat banyak.

Dalam menjalankan fungsinya tersebut, bank melakukan usaha menghimpun dana dari masyarakat dalam bentuk simpanan dan menyalurkan dana yang berasal dari masyarakat dengan cara memberikan berbagai macam kredit.

Bank sebagai lembaga yang memberikan fasilitas kredit menghadapi berbagai konsekuensi seperti resiko. Resiko tersebut berupa kerugian atas keterlambatan dan kemacetan kredit yang mungkin terjadi. Artinya bank menderita kerugian jika fasilitas yang telah dinikmati oleh debitur tidak dapat diterima kembali. Oleh karena itu, pelaksanaannya bank harus memperhatikan asas-asas perkreditan yang sehat agar terhindar dari resiko terjadinya kredit bermasalah.

Undang-Undang No.7 tahun 1992 tentang Perbankan sebagaimana telah diubah dengan Undang-Undang No.10 tahun 1998 menyebutkan bahwa Bank Perkreditan Rakyat sebagai salah satu bank yang kegiatan usahanya ditujukan untuk melayani usaha-usaha kecil dan masyarakat di daerah pedesaan.

Rumusan Masalah

Adapun yang menjadi permasalahan yang akan penulis bahas dalam penelitian ini yaitu :

1. Bagaimana proses pelaksanaan kredit pada Bank Perkreditan Rakyat LPN Pasar Baru Durian Sawahlunto

2. Bagaimana perkembangan kredit dan pengembalian kredit diBank Perkreditan Rakyat LPN Pasar Baru Durian Sawahlunto.

3. Masalah-masalah apa saja yang dihadapi oleh Bank Perkreditan Rakyat LPN Pasar Baru Durian Sawahlunto dalam pelaksanaan penagihan kreditnya dan apa saja kebijaksanaan bank dalam mengatasi hambatan dalam penarikan kredit

\section{LANDASAN TEORI}

\section{Pengertian Kredit}

Istilah Kredit berasal dari bahasa latin yaitu credere yang berarti kepercayaan, atau credo yang berarti saya percaya, artinya kepercayaan dari kreditur (pemberian pinjaman) bahwa debiturnya (penerima pinjaman) akan mengembalikan pinjaman beserta bunganya sesuai dari perjanjian kedua belah pihak. Dalam masyarakat, pengertian kredit sering disamakan dengan pinjaman, artinya bila seseorang mendapat kredit berarti mendapat pinjaman. Dengan demikian, kredit dapat diartikan sebagai tiap-tiap perjanjian suatu 
jasa (prestasi) dan adanya balas jasa (kontra prestasi) di masa yang akan datang.

Undang-Undang No. 10 tahun 1998 tentang perubahan perubahan UU No. 7 tahun 1992 menyebutkan "Kredit adalah penyediaan uang atau tagihan yang dapat dipersamakan dengan itu berdasarkan persetujuan atau kesepakatan pinjam-meminjam antara bank dengan pihak lain yang mewajibkan pihak peminjaman untuk melunasi hutangnya setelah jangka waktu tertentu dengan jumlah bunga, imbalan atau pembagian hasil keuntungan".

\section{Tujuan Kredit}

Keberadaan bank sebagai lembaga keuangan mempunyai peranan yang sangat penting sehingga dapat memotivasi dan mendorong inovasi dalam berbagai cabang kegiatan ekonomi (Suyatno1993; 122).

Bank memberikan kredit dengan tujuan :

a. Mendapatkan pendapatan bank pada hasil bunga kredit yang diterima.

b. Memproduktifkan dan memanfaatkan dana-dana yang ada

c. Menjalankan pada kegiatan operasional bank

d. Menambah modal kerja di perusahaan

e. Mensukseskan program pemerintah dibidang ekonomi dan pembagunan

f. Meningkatkan kesejahteraan dan pendapatan dari masyarakat

Tujuan diatas mencerminkan adanya keseimbangan kepentingan antara pemerintah, masyarakat dan pengusaha sebagai pemilik modal.

\section{Manfaat Kredit}

Manfaat yang diperoleh dari pemberian kredit oleh perbankan, dapat dilihat dari beberapa sudut yaitu :

a. Debitur

Dilihat dari sudut debitur manfaat kredit sebagai berikut :

1) Meningkatkan usahanya dengan pengadaan sejumlah sektor produksi.

2) Kredit bank relatif mudah didapatkan jika usaha debitur diterima untuk dilayani.

3) Memudahkan calon debitur untuk memilih bank yang dengan usahanya.

4) Rahasia keuangan debitur terlindungi.

5) Beraneka macam jenis kredit bisa disesuaikan dengan calon debitur.

b. Pemerintah

Dilihat dari sudut pemerintah manfaat kredit sebagai berikut :

1) Sebagai pemacu pertumbuhan ekonomi secara umum

2) Sebagai pengendali kegiatan moneter

3) Untuk menciptakan lapangan usaha

4) Dapat meningkatkan pendapatan negara

5) Untuk menciptakan dan memperluas pasar

c. Bank

Dilihat dari sudut bank manfaat kredit sebagai berikut :

1) Pemberian kredit untuk mempertahankan dan mengembangkan usaha bank 
2) Membantu memasarkan produk atau jasa perbankan lainnya

3) Memperoleh pendapatan bunga yang diterima dari debitur

4) Dapat rentabilitas bank membaik dan memperoleh laba meningkat

5) Untuk merebut pangsa pasar dalam industri perbankan

d. Masyarakat

Dilihat dari sudut masyarakat manfaat kredit sebagai berikut :

1) Dapat mendorong pertumbuhan dan perluasan perekonomian

2) Mampu mengurangi tingkat pengangguran

3) Memberikan rasa aman kepada masyarakat untuk menyimpan uangnya di bank

4) Dapat meningkatkan pendapatan dari masyarakat

\section{Jenis - Jenis Kredit}

1. Tujuan atau penggunaannya

a. Kredit konsumtif, yaitu kredit yang digunakan untuk pemenuhan kebutuhan sendiri dan dengan keluarganya, misalnya kredit mobil, dan rumah untuk dirinya dan keluarganya.

b. Kredit produktif, yaitu kredit yang diberikan dengan tujuan untuk melancarkan proses produksi. Kredit yang digunakan sebagai penambahan modal baik untuk investasi atau untuk modal kerja bagi penerimaan kredit.

c. Kredit investasi, yaitu kredit yang digunakan untuk investasi produktif, tetapi baru menghasilkan jangka waktu yang relatif lama. Kredit yang biasanya diberikan seperti kredit perkebunan kelapa sawit dan lain sebagainya.

2. Cara pemakaiannya

a. Kredit rekening koran bebas, yaitu kredit yang debitur menerima seluruh dari kreditnya dengan bentuk rekening koran kepadanya diberikan blangko cheque dan rekening korannya pinjamannya diisi berdasarkan besarnya kredit yang diberikan, debitur bebas melakukan penarikan selama kredit berjalan.

b. Kredit rekening koran tidak bebas, yaitu kredit dengan adanya pembatasan tertentu bagi nasabah dalam melakukan penarikan uang rekeningnya. seperti pemberian kredit dengan uang giral dan perubahannya menjadi uang kartal dilakukan berangsur-angsur.

c. Revolusi kredit, yaitu sistem penarikan kredit sama dengan cara rekening koran bebas dengan masa penggunaan satu tahun, akan tetapi cara pemakaiannya berbeda.

d. Term Loan, yaitu sistem penggunaan dan pemakaian kredit yang fleksibel artinya nasabah dapat bebas menggunakan uang kredit untuk keperluan apa saja dan bank tidak mau tentang hal itu.

3. Jangka Waktu

a. Short term credit, yaitu merupakan kredit jangka pendek yang berjangka waktu maksmium satu tahun. Bentuknya berupa kredit direkening koran, kredit penjualan, kredit wesel, dan kredit pembeli serta kredit modal kerja. 
b. Medium term credit, yaitu merupakan kredit jangka menengah yang memiliki waktu antara satu tahun sampai dengan lima tahun.

c. Demond credit, yaitu kredit yang harus dibayar oleh peminjam pada saat kredit diperoleh.

4. Jaminan

a. Kredit tanpa jaminan (unsecured loans), yaitu pemberian kredit dengan tanpa jaminan materil (agunan fisik), pemberian sangat selektif yang ditujukan untuk nasabah besar yang telah teruji kejujuran dan ketaatannya, baik dalam tranksaksi perbankan maupun oleh kegiatan usaha yang dijalaninya. Di Indonesia jenis kredit ini belum banyak digunakan.

b. Kredit Jaminan, yaitu kredit untuk debitur yang didasarkan dari keyakinan atas kemampuan debitur dan adanya agunan atau jaminan berupa fisik (collateral) sebagai jaminan tambahan.

Jenis kredit yang diberikan oleh Bank Perkreditan Rakyat LPN Pasar

Baru Durian Sawahlunto adalah :

a. Kredit modal kerja

Yaitu kredit yang diberikan untuk kepentingan modal kerja debitur atau nasabah yang bersangkutan.

b. Kredit konsumsi

Yaitu kredit yang diberikan untuk keperluan konsumsi berupa barang atau jasa yang dibeli, menyewa ataupun dengan cara lain.

c. Kredit investasi

Yaitu kredit yang diberikan untuk keperluan pembelian barangbarang modal dan jasa yang diperlukan guna modernisasi, ekspansi. relokasi usaha atau pendirian usaha baru.

\section{METODE PENELITIAN}

Dalam mengumpulkan data dan bahan untuk melakukan penelitian ini, digunakan metode pengumpulan data sebagai berikut :

1. Studi Kepustakaan (Library Research)

Memperoleh atau mengumpulkan data perpustakaan untuk mendapatkan literature yang erat kaitannya dengan penulisan tugas akhir ini, juga dari majalah-majalah serta buku-buku.

2. Studi Lapangan (Field Research)

Pemantauan langsung ke objek penelitian dipilih untuk memenuhi hasil data primer. Penelitian langsung ke lapangan ini akan dapat membantu penulis untuk melengkapi data yang diperlukan, adapun cara riset lapangan ini adalah dengan mewawancarai serta melihat pada Bank Perkreditan Rakyat LPN Pasar Baru Durian Sawahlunto.

\section{HASIL DAN PEMBAHASAN}

1. Proses Pemberian Kredit

Proses pemberian kredit oleh Bank Perkreditan Rakyat LPN Pasar Baru Durian Sawahlunto sebagai berikut : 
a. Pengajuan berkas

Dituangkan dalam suatu proposal dengan melampirlan berkas-berkas lainnya yang dibutuhkan antara lain :

1) Latar Belakang Perusahaan

a) Riwayat singkat perusahaan (company profile)

b) Bidang umum

c) Identitas perusahaan (Aspek Legalitas Usaha)

d) Struktur organisasi perusahaan dan susunan pengurus

e) Perkembangan perusahaan serta realisasi dengan pihak-pihak pemerintah dan swasta

2) Maksud dan Tujuan

a) Memperbesar omset penjualan atau meningkatkan kapasitas produksi atau mendirikan pabrik baru (perluasan) serta tujuan lainnya.

b) Pemohon menentukan besarnya jumlah kredit yang ingin diperoleh dan jangka waktu kreditnya. Penilaian kelayakan besarnya kredit dan jangka waktunya dapat dilihat dari cash flow serta laporan keuangan (neraca dan laporan rugi laba) tiga tahun terakhir. Jika dari hasil analisis tidak sesuai dengan permohonan, maka pihak bank tetap berpedoman terhadap hasil analisis mereka dalam memutuskan jumlah kredit dan jangka waktu kredit yang layak diberikan kepada pemohon.

c) Cara pemohon mengembalikan kredit. Dijelaskan secara rinci caracara nasabah dalam mengembalikan kreditnya apakah dari hasil penjualan atau cara lainnya.

3) Jaminan kredit

Hal ini merupakan jaminan untuk menutupi segala risiko terhadap kemungkinan macetnya suatu kredit baik yang ada unsur kesengajaan atau tidak. Penilaian jaminan kredit haruslah teliti agar tidak terjadi sengketa, palsu, dan sebagainya. Pada jaminan ini dilampirkan :

a) Akte Notaris

b) Tanda Daftar Perusahaan (TDP)

c) Nomor Pokok Wajib Pajak (NPWP)

d) Neraca dan Laba Rugi 3 (tiga) tahun terakhir

e) Bukti Diri dari Pengurus / Pimpinan Perusahaan

f) Foto copy Sertifikat Jaminan

b. Penyelidikan Berkas Pinjaman

Tujuannya adalah untuk mengetahui apakah berkas yang diajukan sudah lengkap sesuai persyaratan dan sudah benar. Jika menurut pihak perbankan belum lengkap atau cukup, maka nasabah diminta untuk segera melengkapinya dan apabila sampai batas tertentu nasabah tidak sanggup melengkapi kekurangan tersebut, maka sebaiknya permohonan kredit dibatalkan saja. Untuk mengetahui kelengkapan berkas pinjaman tersebut maka dilakukan hal-hal sebagai berikut : 


\section{1) Wawancara 1}

Merupakan penyidikan kepada calon peminjam secara langsung, untuk mengetahui segala informasi, keinginan dan kebutuhan nasabah yang sebenarnya, serta untuk meyakinkan apakah berkas-berkas tersebut sesuai dan lengkap seperti yang diinginkan oleh bank.

2) On The Spot

Merupakan kegiatan pemeriksaan ke lapangan dengan meninjau berbagai objek yang akan dijadikan usaha atau jaminan. Kemudian hasil on the spot di cocokkan dengan hasil wawancara 1. Pada saat hendak melakukan on the spot hendaknya jangan memberitahu kepada nasabah, sehingga apa yang dilihat dilapangan sesuai dengan kondisi yang sebenarnya.

3) Wawancara 2

Merupakan kegiatan perbaikan berkas, jika mungkin ada kekurangankekurangan pada saat setelah dilakukan on the spot di lapangan. Catatan yang ada pada permohonan dan pada saat wawancara 1 dicocokkan dengan pada saat on the spot apakah ada kesesuaian dan mengandung suatu kebenaran.

2. Perkembangan Pemberian Kredit dan Penerima Kredit BPR LPN Pasar Baru Durian Sawahlunto

Perkembangan pemberian kredit pada Bank Perkreditan Rakyat LPN Pasar Baru Durian Sawahlunto dilihat pada grafik berikut :

\section{Grafik 1 \\ Perkembangan Pemberian Kredit \\ BPR LPN Pasar Baru Durian Sawahlunto \\ Tahun 2010-2014 (Dalam Ribuan Rupiah)}

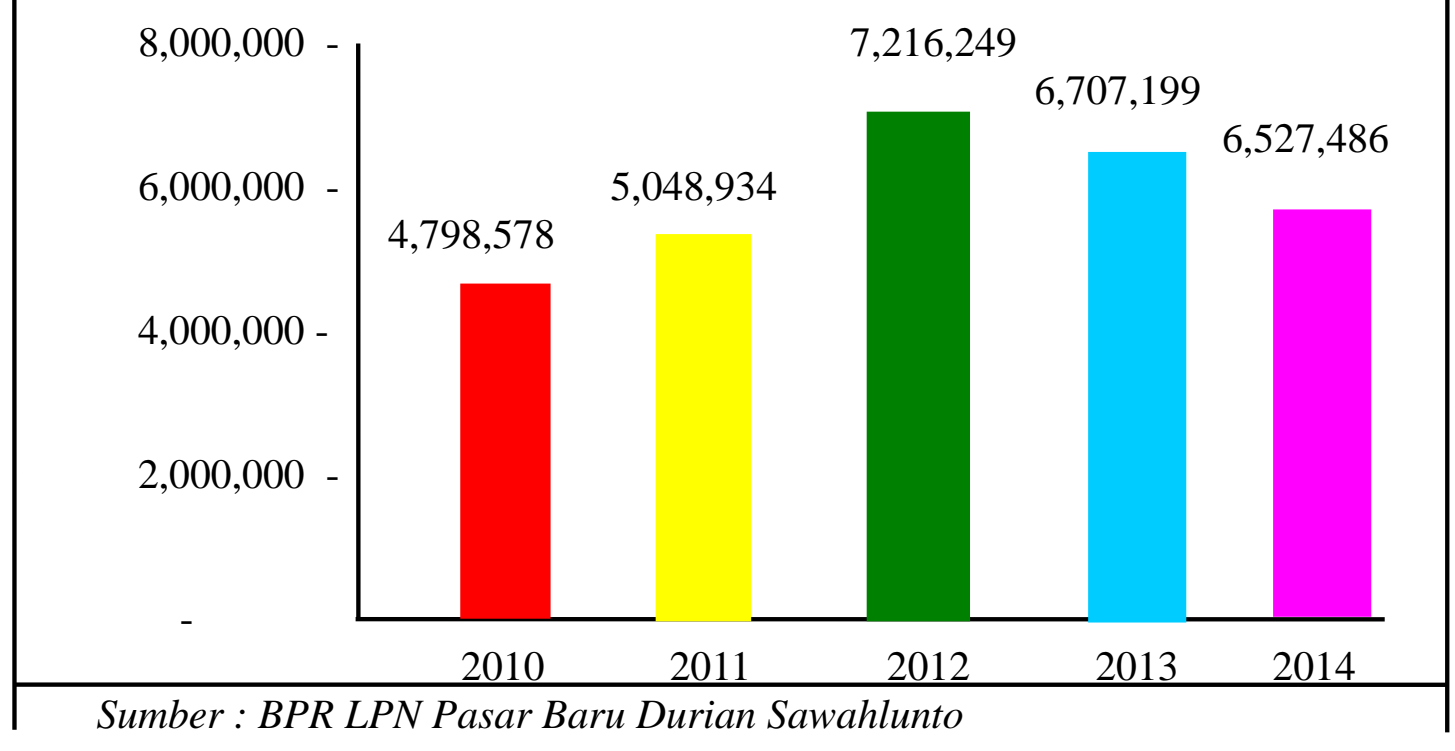


Dari data diatas, dapat diketahui bahwa jumlah pengusaha kecil yang mendapat kredit mengalami peningkatan dan penurunan. Pada tahun 2010 jumlah perkembangan kredit yang diberikan Rp 4,798,578 dan tahun 2011 meningkat menjadi Rp 5,048,934. Pada tahun berikutnya yaitu 2012 terjadi kenaikan yang cukup signifikan menjadi Rp 7,216,249 sedangkan di tahun 2013 mengalami penurunan sebesar Rp 6,707,199. Dan pada tahun 2014 masih mengalami penurunan tetapi tidak terlalu drastis menjadi Rp 6,527,486.

Dilihat dari jumlah penerima kredit pada Bank Perkreditan Rakyat LPN Baru Durian Sawahlunto dapat dilihat pada tabel berikut :

\begin{tabular}{|c|c|c|}
\hline \multicolumn{3}{|c|}{$\begin{array}{c}\text { Tabel 1 } \\
\text { Perkembangan Penerima Kredit } \\
\text { BPR LPN Pasar Baru Durian Sawahlunto } \\
\text { Tahun 2010-2014 }\end{array}$} \\
\hline Tahun & Jumlah Peminjam & Naik/Turun \\
\hline 2010 & 495 & - \\
\hline 2011 & 518 & Naik \\
\hline 2012 & 597 & Naik \\
\hline 2013 & 544 & Turun \\
\hline 2014 & 608 & Naik \\
\hline
\end{tabular}

Sumber : BPR LPN Pasar Baru Durian Sawahlunto

Dari data diatas dapat diketahui bahwa penerima kredit pada Bank Perkreditan Rakyat LPN Pasar Baru Durian Sawahlunto pada tahun 2010 berjumlah 495 orang. Pada tahun 2011 penerimaan kredit mengalami peningkatan sebanyak 518 orang dan tahun 2012 juga masih mengalami peningkatan sebanyak 597 orang. Pada tahun 2013 penerimaan kredit mengalami penurunan sebanyak 544 orang. Dan pada tahun 2014 mengalami kenaikan yang cukup signifikan sebaynyak 608 orang.

Dilihat dari jumlah peminjam pada tahun 2013 Bank Perkreditan Rakyat LPN Pasar Baru Durian Sawahlunto mengalami penurunan jumlah peminjam, hal ini disebabkan karena adanya kredit macet sehingga berkurangnya kepercayaan bank terhadap debitur yang tidak bisa mengembalikan pinjaman tersebut beserta bunganya sesuai dengan kesepakatan yang telah disepakati kedua belah pihak. Dan pada tahun 2014 mengalami peningkatan kembali yaitu 608 orang, hal inilah yang memicu kembali berkembangnya penerima kredit pada Bank Perkreditan Rakyat LPN Pasar Baru Durian Sawahlunto. 
Dilihat dari penerima dan pemberian kredit pada Bank Perkreditan Rakyat LPN Pasar Baru Durian Sawahlunto tahun 2014 terjadi perbedaan. Penerima kredit tahun 2014 mengalami kenaikan sedangkan pemberian kredit mengalami penurunan. Perbedaan tersebut dikarenakan dana kredit yang diberikan kepada penerima dalam jumlah yang besar.

3. Masalah-masalah yang dihadapi oleh Bank Perkreditan Rakyat LPN Pasar Baru Durian Sawahlunto dalam pelaksanaan penagihan kreditnya dan kebijaksanaan bank dalam mengatasi hambatan dalam penarikan kredit.

Penyebab terjadinya masalah pada Bank Perkreditan Rakyat LPN Pasar Baru Durian Sawahlunto yaitu :

a. Faktor Intern Nasabah

1) Itikad tidak baik dari debitur, seperti :

a) Karena sudah menunggak, merasa tidak dapat lagi dibantu oleh bank.

b) Berpendapat bila kredit belum dilunasi, tunggakan dibayar atau beberapa bulan atau tahun kemudian tidak akan dikenakan denda.

c) Merasa bahwa bank juga membutuhkannya, karena ia juga dapat pindah ke bank lain yang juga sama membutuhkannya.

d) Jumlah tunggakan sudah terlanjur besar sehingga terasa berat untuk membayarnya.

2) Menurunnya usaha debitur mengakibatkan turunnya kemampuan debitur untuk membayar angsuran.

3) Debitur tidak mempunyai pengetahuan dan pengalaman yang cukup untuk mengelola usaha, sehingga usaha debitur tidak berjalan dengan baik.

4) Ketidak jujuran debitur dalam penggunaan kredit untuk produktif menjadi kredit konsumtif yang tidak sesuai dengan tujuan semula dalam perjanjian kredit.

b. Faktor Ekstern Nasabah

1) Force majeur

Perubahan-perubahan yang terjadi karena bencana alam yang dapat menyebabkan kerugian besar bagi debitur dalam usahanya. Perubahan ini antara lain bencana alam seperti banjir, tanah longsor, kebakaran, dan lain sebagainya.

2) Akibat perubahan-perubahan eksternal lingkungan (environtment)

Perubahan ekonomi karena krisis moneter yang berpengaruh terhadap usaha debitur. Krisis moneter tersebut dapat menyebabkan terjadinya inflasi yang dapat menyebabkan nilai uang menurun terhadap mata uang asing. Harga barang-barang naik, menyebabkan daya beli masyarakat menurun. Kebalikan dari inflasi adalah deflasi yang dapat menyebabkan nilai uang naik terhadap mata uang asing sehingga barang-barang turun, yang menyebabkan berkurangnya produktifitas perusahaan. 
c. Faktor Intern Bank

1) Itikad tidak baik dari petugas bank untuk kepentingan pribadi, seperti pegawai bank merealisir kredit debitur yang memberi imbalan atas pencairan kredit tersebut.

2) Kurangnya kemampuan petugas bank dalam pengelolaan pemberian kredit mulai dari pengajuan permohonan sampai pencairan kredit.

3) Kelemahan dan kurang efektifnya petugas bank dalam membina debitur, sehingga debitur mudah memanfaatkan keadaan ini untuk mencoba melakukan pelanggaran maupun ingkar janji (wanprestasi).

d. Faktor Ekstern Bank.

1) Adanya kesulitan atau kegagalan dalam proses likuiditas dari perjanjian kredit yang telah disepakati antara debitur dengan bank.

2) Kondisi manajemen dan lingkungan usaha debitur.

Dalam mengatasi masalah kredit Bank Perkreditan Rakyat LPN Pasar Baru Durian Sawahlunto membedakan antara kredit berjalan tidak lancar dengan kredit macet sebagai berikut :

a. Kredit yang berjalan tidak lancar

Langkah-langkah yang diambil antara lain :

1) Pelaksanaan Legal Limit Lending (LLL)

Yaitu pemberian batasan terhadap jumlah pinjaman maksimum yang akan diberikan kepada nasabah dengan tujuan agar nasabah yang akan meminjam memikirkan terlebih dahulu bebrapa jumlah pinjaman yang akan diajukan kepada pihak bank.

2) Penyelesaian kredit secara damai

Dalam hal ini dapat dilakukan terlebih dahulu kepada nasabah bahwa kreditnya sudah jatuh tempo dan menunggak.

3) Bila tidak berhasil, maka nasabah tersebut akan dilaporkan kepada kantor cabang dan dimasukkan ke dalam daftar peminjam yang bermasalah.

4) Laporkan kepada pihak berwajib bahwa nasabah tersebur tidak melaksanakan kewajibannya dan pihak berwajib akan bertindak tegas dengan menyita aset yang dimiliki nasabah tersebut untuk kemudian dijual untuk menutupi jumlah pinjaman dan bunganya.

5) Apabila aset yang dilelang tersebut tidak juga menutupi jumlah pinjaman dan bunga nasabah tersebut, maka tindakan jalur hukum akan ditempuh sebagai upaya terakhir.

b. Kredit macet

Langkah-langkah yang diambil antara lain :

1) Rescheduling (Penjadwalan Ulang)

Yaitu perubahan syarat kredit hanya menyangkut jadwal pembayaran dan atau jangka waktu termasuk masa tenggang dan perubahan besarnya angsuran kredit. Kebijakan ini hanya kepada debitur yang menunjukkan itikad dan karakter yang jujur dan memiliki kemauan untuk melunasi kredit 
2) Reconditioning (Persyaratan Ulang)

Yaitu perubahan sebagian atau seluruh syarat-syarat kredit yang tidak terbatas pada perubahan jadwal pembayaran, jangka waktu, tingkat suku bunga, penundaan pembayaran sebagian atau seluruh bunga dan persyaratan lainnya. Debitur yang bersifat jujur, terbuka dan cooperative yang usahanya sedang mengalami kesulitan keuangan dan diperkirakan masih dapat beroperasi dengan menguntungkan, kreditnya dapat dipertimbangkan untuk dilakukan persyaratan ulang.

3) Restructuring (Penataan Kembali)

Yaitu perubahan syarat-syarat kredit berupa penambahan dana bank dan atau konversi seluruh atau sebagian tunggakan bunga menjadi pokok kredit baru, konversi seluruh atau sebagian dari kredit menjadi penyertaan dalam perusahaan.

4) Liquidation (Liquidasi)

Yaitu penjualan barang-barang yang dijadikan jaminan dalam rangka pelunasan utang. Pelaksanaan likuidasi ini dilakukan terhadap kategori kredit yang memang benar-benar menurut bank sudah tidak dapat lagi dibantu untuk disehatkan kembali atau usaha nasabah yang sudah tidak memiliki prospek untuk dikembangkan.

\section{KESIMPULAN DAN SARAN}

1. Kesimpulan

Dengan penjelasan serta pembahasan tentang pelaksanaan kredit, maka dapat disimpulkan :

a. Proses pemberian kredit yang dilakukan oleh Bank Perkreditan Rakyat LPN Pasar Baru Durian Sawahlunto dimulai dari pengajuan berkas, penyelidikan berkas pinjaman, keputusan kredit, dan diakhiri dengan realisasi kredit. Setelah itu barulah dilakukan pengawasan kredit.

b. Perkembangan kredit pada Bank Perkreditan Rakyat LPN Pasar Baru Durian Sawahlunto baik dilihat dari jumlah kredit yang diberikan maupun jumlah penerima pinjaman tahun 2010-2014 pada dasarnya mengalami peningkatan dengan jumlah pemberian kredit dari Rp 4,798,578 sampai dengan $\mathrm{Rp} 7,216,249$ dengan jumlah penerima kredit dari 495 sampai 608 orang walaupun pada tahun 2013 mengalami penurunan yang disebabkan karena adanya kredit macet sehingga berkurangnya kepercayaan bank terhadap debitur yang tidak bisa mengembalikan pinjaman tersebut beserta bunganya sesuai dengan kesepakatan yang telah disepakati kedua belah pihak. Sehingga bank pada saat itu sangat memperhatikan penyeleksian pemberian kredit.

c. Permasalahan yang dihadapi oleh Bank Perkreditan Rakyat LPN Pasar Baru Durian masih adanya nasabah yang membayar tidak pada waktunya, dalam hal ini Bank Perkreditan Rakyat LPN Pasar Baru 
Durian Sawahlunto mengatasinya dengan jalan kekeluargaan seperti rescheduling (penjadwalan kembali), reconditioning (persyaratan ulang), restructuring (penataan kembali) dan apabila masalah tersebut tidak bisa diselesaikan secara damai barulah penyelesainnya dengan jalan hukum.

2. Saran

a. Bank Perkreditan Rakyat LPN Pasar Baru Durian Sawahlunto sebagai satu-satunya BPR yang masih aktif di kota Sawahlunto hendaknya tetap mempertahankan visi dan misi Bank agar tetap menjadi Bank yang sehat dan bisa bertahan lama.

b. Karyawan Bank Perkreditan Rakyat LPN Pasar Baru Durian Sawahlunto hendaknya dapat memberikan pelayanan semaksimal mungkin terhadap nasabah dalam rangka promosi menarik minat masyarakat agar tidak ada keraguan dalam berhubungan dengan bank.

c. Untuk menghindari hal-hal yang tidak diinginkan yang dapat merugikan pihak Bank Perkreditan Rakyat LPN Pasar Baru Durian Sawahlunto, maka bank harus selektif dalam menerima nasabah.

\section{DAFTAR PUSTAKA}

Alanshari, F., \& Marlius, D. (2018). Prosedur Pemberian Kredit KPR Pada PT. Bank Tabungan Negara (Persero) TBK Cabang Pembantu Bukittinggi. https://doi.org/10.31227/osf.io/rsfhc

Amelia, L., \& Marlius, D. (2018). Pengendalian Kredit Dalam Upaya Menciptakan Bank Yang Sehat Pada PT. Bank Pembangunan Daerah Sumatera Barat Cabang Utama Padang. https://doi.org/10.31227/osf.io/kpc64

Andriani, B., \& Susanto, R. (2019). Pengawasan Kredit PT. Bank Perkreditan Rakyat (BPR) Ophir Pasaman Barat. https://doi.org/10.31219/osf.io/aunvc

Adinugroho, Tjipto, Perbankan masalah perkreditan, Penerbit Pradya Paramita, Jakarta, 1973.

Baiya, \& Fernos, J. (2019). Analisis Faktor-Faktor Penyebab Kredit Macet Pada Bank Nagari Cabang Siteba. https://doi.org/10.31227/osf.io/4xuks

Darmawanto, \& Fernos, J. (2019). Prosedur Pemberian Kredit Pada Bank Nagari Cabang Sijunjung. https://doi.org/10.31227/osf.io/psqfy

Firmansyah, A., \& Fernos, J. (2019). Analisis Kredit Bermasalah Dilihat Dari Standar Non Performing Loan (NPL) Pada PT. Bank Perkreditan 
Rakyat (BPR) Prima Mulia Anugrah Cabang Padang. https://doi.org/10.31227/osf.io/gcj94

Orlando, A., \& Susanto, R. (2019). Mekanisme Pencairan Kredit Usaha Rakyat Pada PT. Bank Rakyat Indonesia Unit Lubuk Buaya. https://doi.org/10.31219/osf.io/zuv2y

Ikbal, M., \& Marlius, D. (2017). Pengaruh Jumlah Taksiran Dan Uang Pinjaman Terhadap Laba Bersih Pada PT. Pegadaian (UPC) Gurun Laweh. https://doi.org/10.31227/osf.io/uch4a

Kooents, Odonnel Cery, Prinsip-prinsip Management, Penerbit Bharata, Jakarta 1972.

Manulang, M, Pengantar Ekonomi Perusahaan, Penerbit Ghalia Indonesia, Jakarta, 1975.

Shanjaya, A. R., \& Marlius, D. (2017). Peranan Laporan Keuangan Dalam Kebijaksanaan Pemberian Kredit Kepada Calon Nasabah Pada PT. BPR Batang Kapas. https://doi.org/10.31227/osf.io/uxmg6

Sinungan, Mukhdiansyah, Kredit Seluk Beluk dan Teknis Pengolahan, BPFE, Yogyakarta, 1978.

Sutarso, Dasar-dasar Akuntansi, UGM, Yogyakarta, 1982.

Siagian, P, Filsafat Administrasi, Penerbit Gunung Agung, Jakarta 1975. 